\title{
Observing observers in social systems theory An interview with Hans-Georg Moeller
}

\author{
Laurindo Dias Minhoto* \\ https://orcid.org/0000-0001-6388-9669 \\ Lucas Fucci Amato* \\ https://orcid.org/0000-0002-8923-8300 \\ Marco Antonio Loschiavo Leme de Barros** \\ https://orcid.org/0000-0001-9465-8783
}

Introduction

On November $4^{\text {th }}, 2019$, Hans-Georg Moeller delivered a presentation on systems theory at the Law School of the University of São Paulo and was interviewed about Niklas Luhmann's theory of society, with emphasis on issues such as law, politics, and the history of philosophy. Professor Moeller is the author of important books such as Lubmann explained: From souls to systems (Moeller, 2006) and The radical Luhmann (Moeller, 2011), the latter also translated to Japanese and Italian. He also works on Chinese philosophy and is currently Full Professor at the Department of Philosophy and Religious Studies in the Faculty of Arts and Humanities of the University of Macau, China.

Throughout the interview, professor Moeller situated Luhmann in the philosophical tradition of German idealism and presented the shift to second-order observation as a crucial aspect of contemporary society, in religion and politics, science, economy and law. The interview was conducted partly in writing and partly in the form of a recorded and transcribed debate.

* Universidade de São Paulo, São Paulo, Brasil.

** Universidade Presbiteriana Mackenzie, São Paulo, Brasil. 
Our first interest is to know how did you get in touch with systems theory?

Hans-Georg Moeller (H-GM): I guess I am one of those few people - maybe not so few after all - who don't really have a strong background in Luhmann's circles. I never met Niklas Luhmann. I never went to his lectures. So, I was an autodidact. The reason why I got interested in his theory was because of its popularity in academic circles in the 1980's and 1990's. My academic maturation occurred during the decades in which Luhmann was probably the most innovative and most exciting theorist in German, then I started reading his books and found the theory the more I read it the more applicable to contemporary society. Maybe what helped is that I did my major at the University of Bohn on Chinese studies and my minor was on Philosophy where my studies were mainly on Kant and Hegel, and Luhmann is, in many ways, the person in Germany who - as Habermas said - follows in the footsteps of these modern philosophers in doing a "super-theory", as Luhmann called it.

This theoretical grand project places Luhmann, as Geoffrey Winthrop-Young put it, as a kind of heir of Hegel's throne. In this sense, Luhmann tried to do something similar to what Hegel and Kant did in their historical time. I think there are some core ideas, particularly the constructivist element of the theory, that are strongly rooted in the Kantian tradition. So that's maybe also why I found the theory very interesting.

Concerning this vision of Lubmann as a kind of Hegel's heir, do you see some space for reading Luhmannian theory in a critical vein, i.e., for the emergence of a new Marxist, or left Hegelian reading of systems theory?

H-G M: I do think so, definitively. Maybe it doesn't really happen in Germany and I don't really see it anywhere else because Luhmann is normally seen as a kind of opposition to critical theory, either apolitical or even conservative or rightist, which I think is wrong. Well, Marx was also a Hegelian, of course, and also had this project of a "super-theory". Luhmann speaks sometimes dismissively about Marx, that's maybe a little bit polemic. On the one hand, Marxists would profit from reading more Luhmann, by understanding how society and specifically the economy has developed. So, I think Marxism is in need to move forward to the 21st century. And see how society has changed and that these old categories can't really simply apply in the same way as in the $19^{\text {th }}$ century. On the other hand, systems theoreticians would also profit from studying more of Marxism, in order to develop - maybe we can say - a more critical perspective. I still think that the non-normative aspect of 
Luhmann is very important, but I also think that being normative and being critical are different positions. Luhmann is extremely critical, but he is not trying to be normative. And, again, this is something that the left should listen to. The left has to a large extent replaced critical thinking by normative, moralist thinking, to the detriment of itself, particularly in Europe and in the United States. I'm not sure if that is the case here in Brazil, but there the left turned very much to identity politics and political correctness, which has led the left to "abandon the working class", as Noam Chomsky has put it. The left has basically abandoned the class issue, and economic issues, because they switched to a normative, moralist discourse, and that's not very helpful. The left needs more social theory rather than moralism. On the other hand, Luhmannians may also need a little more attention towards concrete social issues that were traditionally approached by Marxists.

From the point of view of the scientific system, Lubmann's emphasis is always on the descriptive level of analysis. But in other social subsystems we have some normative discourses going on, for instance, through the categories of "contingency formulas", such as "justice" in the legal system and the idea that we can couple technical consistency and social irritability or responsibility. Maybe this can indicate some possibility for an immanent critique operating from within different social subsystems. Do you think this is possible?

H-G M: Absolutely. In a Kantian sense, a critique is a reflection on conditions of possibilities. Now, that sounds very abstract, but what a good theory does is not taking the current dominant descriptions of what society is at face value, it questions why society describes itself in these particular ways. In a way this is a critique of the dominating values. Luhmann talks a lot about structures and semantics, how the two sides are related, how social structures eventually bring about new semantics, and how semantics supports social structures. This is a very Marxist conception. The function of critique here is precisely that which Marx aimed at: why do people believe in family or a certain notion of justice, why are these important categories, why does it have such a strong normative power of determining values? We could do something similar with Luhmann. We then can approach very concrete social contexts, observing values in the economy, in the religion and other fields, like law.

Kant is considered to have made a "Copernican revolution" in epistemology. What would you consider the most disruptive aspect of Luhmann's project in relation to the Kantian constructivism? In this sense, how do you observe the attempts to build a "critical systems theory"? Can we use concepts such as "functional differentiation" as 
normative criteria? In addition, how do you consider the distinction between normative (or critical) and descriptive (or analytical) social research? If we consider Luhmann as a radical constructivist, is it still worth differentiating a normative from a descriptive perspective in Lubmann's theory?

H-G M: I think that Kant's "Copernican turn" is probably the most decisive philosophical resource for Lubmann's radical constructivism. Instead of observing the "things in themselves" we must, as theoreticians, observe how they are observed. This is a fundamental theoretical link between Kant and Lubmann. Nearly equally important for Lubmann is Kant's concept of critique - which is by no means simply a value judgment about "good" or bad" - but an analysis of the "conditions of possibility" of something. In this sense "critique" is almost opposed to "normativity". It does not judge, but analyze. However, Kant not only eventually supplements his critique with normativity, he even grounds normativity in critique. Luhmann does not make this step. He remains firmly on the critical side and avoids normativity in favor of descriptivity - with two possible exceptions, namely a) functional differentiation is worth preserving, and b) (paradoxically) normativity is bad (in theory), and morality is (potentially) bad in society. In my view, we should go beyond the simplistic Habermas vs. Luhmann or normative vs. descriptive framework. Lubmann is not only grounded in Kant, but also in the Stoics and in Spinoza. From these sources, he adopts an almost therapeutic approach to theory: by making sense of the world, we can realize how limited the notion of human agency in it is. Thereby we can achieve some sort of equanimity through theory, and thereby we can refrain from further increasing suffering of others and ourselves through futile and often harmful attempts to "change the world", for instance according to ideological or religious convictions or beliefs. I would therefore summarize the theoretical attitude I take from Lubmann with three distinctions: Subversive, but not revolutionary; Therapeutic, but not normative; Critical, but not judgmental.

In your book The Radical Lubmann (Moeller, 2011), you present a historical-philosophical account of Luhmann's theory. This is an important, yet unusualperspective since Luhmann's works is usually presented within the sociological tradition. Moreover, you indicate that Lubmann tries to develop a kind of "post-philosophical" semantics. Could you explain this concept? Would this be the case for a new perspective that integrates sociology and philosophy?

H-G M: Let me try to answer indirectly. For me one of the most important theoretical points that Luhmann made is the transition from necessity to contingency. Here we find a core difference between the Hegelian project and the Luhmannian 
project. Hegel looks at what happens in the world, and everything that happens in the world seems contingent, arbitrary, coincidental. Then we need theory, particularly philosophy, for understanding why things somehow need to be the way they are, why this all develops and make sense. For Hegel the function of philosophy is to provide the conceptual framework that transforms all the apparent contingency into necessity, different from religious necessity: this is not because God wanted this, not because it is good in this way, but because somehow in society this is an evolutionary, developmental necessity. There is a certain rationality behind all these things. On the other hand, I called Luhmann's project "post-philosophical" in the sense that for him it is the other way around: his criticism transforms necessity into contingency. There is a strong post-modernist influence on him, by Deleuze and others. We take events that seem rational and meaningful to us and then we analyze how meaning is very much socially contingent. How things that we take for granted, in the legal or scientific system, for instance, have to do with the function and the communicational operations that establish this meaning, and that have evolved in specific circumstances. For Luhmann it is always super unlikely, for instance, that we would be here, discussing in this room today. For us it seems very meaningful, but for the vast majority of the people, if they come to watch this interview, they wouldn't understand the purpose of it. It is highly contingent, considering our individual biographies and particularly the social systems within which we operate right now. Whatever is meaningful for us is weird for almost everyone else. That is transforming necessity into contingency. Luhmann's theory enables us to see how society works precisely because of this weirdness, and not despite of it. We then can understand why we talk about "truth" in philosophy, how social systems evolved and developed such unlikely "contingency formulae" like "truth" or "justice" which are very complex and a product of a long evolutionary social processes.

\section{In which way does the plurality of contingency formulae limit the potential for coordi- nated social actions?}

H-G M: The descriptions we give through these formulas such as "justice", "legitimacy" or "truth" are highly contingent. This is a point on which Luhmann reflects very much. We do not get out of society; this also means that we can't really come up with some form of valid description which is immediately understandable to everyone else. Any description we give needs to be processed as communication. And this is a problem for critical theory: we can't just speak for the workers. That's also what makes critical theory and social action so complicated. There isn't a common ground anymore and philosophy cannot establish this common ground anymore, which was still an idea 
very much present in Marx: we can educate the people and then we can have a common language and coordinated action. For systems theory, everyone is building the ivory tower, each system is building its ivory tower. It is not just the academics that have their ivory tower, and then there would be the rest of the world... Every system is in an ivory tower, but sometimes some of them become more powerful and the others become increasingly marginal. Within the limits of the scientific system. Luhmann's theory allows us to reflect on the marginality of philosophy and the limits of steering.

This connects with a kind of democratic posture in Luhmann, in not believing in hierarchical orders, and in rejecting the primacy of science or of any privileged point of view.

H-G M: In systems theory we find this motto: "neither hope nor fear". It isn't meant to provide some ideology or consolation, some kind of religious attitude. The purpose of theory is not to build a foundation for false hopes. To the contrary: one of its functions is to show how unfounded certain hopes, such as the hope for a primacy of science. But, on the other hand, we must not be fearful. Theory allows us to "de-construct" the reigning ideologies. There are very strong stoic elements in Luhmann's theory, and also an influence of Spinoza. Theory is reflection, just like for the stoics. Within theory, we can see the limits of theory itself. This has a therapeutic effect, we see the vanity of certain claims to hierarchical supremacy. Politics or the law cannot really rule over philosophy or theory, but philosophy or theory cannot determine politics or the law. In this way we don't dive into fanaticism.

In your book The radical Lubmann (Moeller, 2011) you highlight different aspects of radicalization of Luhmann's theory and argue that his work can been seen as an important paradigmatic shift in social theory. However, Luhmann's work has not been widely compared with other "contemporary" social thinkers like Habermas, Bourdieu and Foucault. Additionally, for instance, in Brazil, systems theory studies are much more connected to Law Schools rather than to Sociology Departments. How do you see the developments of systems theory in Europe and Asia? Could we observe any differences regarding subjects, disciplines, methodology, etc.? Do you think that this difficulty of a diffusion of Lubmann's theory can be partially explained by his radicality? Does radicality lead to isolation in science?

H-G M: I am not (anymore) mainly interested in "explaining Luhmann" or reconstructing what exactly he meant. I am not interested in mere exegesis or applying his 
theory in an "orthodox" way. Such approaches still exist (especially in Germany), but what is more interesting is using the theory to explain contemporary developments - many of which took place after Luhmann's death. Elena Esposito is a "role model" for how to apply Luhmann's theory when analyzing, for instance, the financial economy or the increasing role of algorithmic communication. The point is to not merely compare Luhmann with postmodernists or others, but to reach a "post-comparative" stage where we use Luhmann's theory to develop new theoretical models - which is exactly what Luhmann wanted to be done with his theory. These developments still happen at the fringes of the academic system and of its respective "disciplines", but they happen. I am still convinced that Luhmann's theory provides the best available theoretical resources for understanding contemporary society. One reason why Luhmann's theory is difficult to understand and never became mainstream (there are many such reasons) is that it disappoints normative expectations; it does not provide easy answers to the questions of what is right or wrong, or what needs to be done. One aspect of the radicality of the theory is that it is radically anti-normative in a society which highly values and rewards normative communication. It subverts and disrupts normative discourse, a normative mindset, and a normative way of life. This may lead to a kind of "isolation".

In a well-known article, Lubmann (1997) observes that the worst-case scenario for the XXI century would be the emergence of a metacode of inclusion and exclusion transversally conditioning the operation of different social systems. In this text, he also affirms that the idea of exploitation constitutes an "outdated mythology", suggesting that functional systems activate a social dynamic of "global neglect" " the calamity is no longer exploitation and suppression but neglect"). In this scenario, "two forms of integration will compete: the negative integration of exclusions and the positive integration of inclusions. After more than twenty years, do you think that this tendency has been empirically confirmed? To what extent could this analysis contribute to an understanding of labor relations in the so-called "gig economy" and of the deepening of social cleavages in world society? Complementing, in your evaluation, is Lubmann's theory just a good description for the North Atlantic, for all Western countries, or is it really a theory able to explain the world society? Do you see, for instance, functional differentiation working in the same way in all regions?

H-G M: I am not sure that "inclusion/ exclusion" has worked out in the way Luhmann envisioned it some decades ago. I think he got the idea in part from visiting Brazil and learning about the favelas. He refers to them in the article you mention. I don't think that the favelas or the people who live there are functionally excluded. They 
appear in the media, they are religious, there's a highly profitable economy going on there (drugs, even tourism), they're politically important, and the legal system deals with them all the time. Perhaps most significantly they are as active on the social media just as anyone else. The people there are not functionally neglected at all. Exploitation still exists and "flourishes" on a massive scale. For instance Macau, where I live, is full of migrant workers from mainland China and South East Asia who work very long hours for very little money in a place that is one of the richest in the world. I think that the capitalist economy is obviously highly exploitative. Luhmann apparently did not wish to admit this - it would have disturbed his conceptual system, perhaps. I think that another distinction that is somewhat related to inclusion/exclusion is becoming more relevant for the $21^{\text {st }}$ century: high profile/ low profile. Everyone strives towards high profile and tries to avoid low profile. That is the case as much at the University of Sao Paulo as in the favelas, I suppose, although it means something very different in each context/system. When it gets to the details, Luhmann's theory is not only Eurocentric, but "Germanocentric". He mentions China from time to time, for instance, but only pre-modern China. $\mathrm{He}$ obviously read stuff on China, but what he took from these readings is almost always very superficial. When reading this, I often think si tacuisses, philosophus mansisses (if you had remained silent, you would have remained a philosopher). And I sometimes get the same feeling when he writes about Brazil, or the USA. This being said, as mentioned, I still think that the general framework of the theory, including the notion of a "world society", is most relevant for making sense of today's global society.

Habermas (1987) considered in his book on The philosophical discourse of modernity that Lubmann was the most radical author in the way of emptying out his theory of all normative claim. However, when it comes to some concepts, such as functional differentiation, de-differentiation or systemic corruption (or colonization), it sounds as Lubmann observes them with an evaluative bias. When do we have dysfunctional de-differentiation and when do we have just a structural coupling?

H-G M: I think that's a very good point and Luhmann is actually often quite contradictory and not very clear. The theory is not as clear cut and clean as many of the Luhmannians pretend it is. When is there a case of normal structural coupling and when do we see that one system is basically usurping or corrupting another system? It's very difficult to make this distinction. We can have structural couplings, provided that the systems remain operationally closed. Once operational closure is subverted, they are corrupted. Then the question is how operationally closed empirically systems really are- which in theory they must be, from an orthodox Luhmannian 
view. It would be up to those who conduct more empirical work to find this out. An interesting case of corruption within functional differentiation may be the role of religion today, overlapping with the political system in Brazil for instance. And do we have functional differentiation in Brazil or in China? We just had a workshop in Bielefeld on how far systems theory applies to China. Luhmann's works are being translated by legal scholars in China and they are concerned that maybe there isn't really functional differentiation there, particularly no functional differentiation of law, which is politically controlled.

Maybe there tends to be corruption, not functional differentiation, if there aren't some institutionalized, procedural, even bureaucratic ways to publicly link one system to another. This seems to be the case of today's religious clientelism, which exploits social exclusion in order to gain political positions.

H-G M: I think that Luhmann is wrong in many aspects of his theorization about social exclusion. One of the systems that includes very well is the religious system. It works as a system of inclusion, and then pushes forth inclusion in other areas, such as politics.

So, religion works as a last resource for inclusion. And then, through religious inclusion, some social groups from their economic communities, come to run their businesses, gain access to education, to politics etc. But, while promoting inclusion in other systems, religion also corrupts them in order to expand its operations. The recent electoral process in Brazil (2018) has confirmed the increasingly political importance of the so-called neo-Pentecostal sects in the country, such as the Universal Church of the Kingdom of God. Many political representatives attached to these sects were elected, including the president himself. This political prominence seems to be tightly associated to the adoption of aggressive economic strategies in the religious global market in which the controlling of mass media (including $T V$ and radio networks), the profit motive and a theology of prosperity and economic success play a decisive role. To what extent could systems theory contribute to shed light on this sort of "religious industry" and the current articulation between religious, economic, and political motives involved therein?

H-G M: Luhmann was highly critical about morality and regarded it as potentially highly pathological, as very close to conflict and violence. I think this critical insight can be easily extended to religion, because religions often turn out to be something like the social institutionalization of moral discourse. Luhmann was right, I believe: There is no moral system, all systems can use moral communication. But the religious 
system lends itself to become almost a social "reification" of morality. Brazil seems to be just one example for how powerful, destructive, and "parasitic" religion can become. In the form of fundamentalism, it can become a major threat to functional differentiation. I therefore think that theory, and especially social theory, should be much more critical of religion as it currently is. In this regard, I sympathize with Marxism and its critique of religion, although I would never advocate political or legal suppression of religion. Luhmann claimed that the function of ethics could be to warn against morality, and I think that, similarly, a function of social theory could be to warn against religion - and especially against highly moralistic forms of religion - but not to censor it, of course. Paradoxically, the fact that theorists today tend not to warn against the social (and psychological) pathologies stemming from religion is itself grounded in a form of "civil religion" or what is often called "political correctness". Just like morality, religion is somehow supposed to be "good". As if to protect its religious origins and characteristics, civil religion tends to morally condemn critiques of religion. Civil religion - in the form of "political correctness" - can become just as fundamentalist as traditional religion, and, in some ways, it has already succeeded in emptying the political "left" of its critical and materialist (social-theoretical) core and turned it into a pseudo-left, a moralist, and often highly bourgeoisie or capitalist discourse. In Brazil, it seems, the electorate has now only the choice between a traditionally religious right profile or a civil religious left profile. The left, it sometimes seems, has lost the guts to subvert and critique religion - and succumbed to civil religion.

To achieve some degree of closure, systems presuppose a total inclusion of people, the universal relevance of their operations. However, in order to promote such inclusion - or a significant portion of it - we need to rely on a specific system, whose empowerment threatens the autonomy of the other systems. Like politics in relation to economy, education or any area of public policy. This is the point of Lubmann's criticism of the Welfare State (Luhmann, 1990): the risk of politicization, the political de-differentiation of some systems in order to promote inclusion - what leads to new differences and inequalities. We come to a paradox.

H-G M: Yes, I agree. And also I agree that here we can see some sort of normativity in Luhmann. The other paradoxical point of normativity in Luhmann is that he is normatively against normativity! This appears on his very strong critique of morality, of moral discourse. But he is not afraid of paradoxes. This is also something that we can learn. And the religious system is "infected" by morality; Luhmann used to talk about morality as a form of pathology, of a communicational illness that infects 
any given social system. He is very much interested in social pathologies - such as the corruption of functional differentiation. In this sense, the religious system is very vulnerable to infection by moral communication, and once it is infected, it infects other social systems. Via religion a highly moralist discourse, a moral virus can spread to politics. The media is also a system of communication deeply marked by selection of information through its moral appeal. Which brings us to the social media, a topic on which Luhmann did write about. This is a critical potential in Luhmann: to look on how these normative discourses are extending into many areas of society and threaten the autonomy of systems (media, politics, law). From a Luhmannian perspective, rather than having highly technical discussions - like ivory tower technical discussion - as sociologists and legal scholars usually have them, I think it would be good to look at such critical potentials - critiquing how morality "corrupts" autopoietic systems. Again, as "stoics", we may counter the fundamentalist mindsets found everywhere, in right-wing as in left-wing discourse. This recalls Marx famous metaphor of religion as the "opium of the people". This is a strong parallel between Marx and Luhmann.

Roberto Unger (2014) recognizes three big world religious trends: Buddhism is identified with the overcoming of the world, the search for serenity; Confucianism has a view of humanization and attaches value to role-based claims; the religions of salvation, finally, includingJudaism, Christianity and Islam, are the affirmation of individuality in a struggle with the world. In your view, could we observe a globalization of these religions now, in the sense that all of them are not anymore limited to some region of the world? Would this be an indication of a world society? Do you think that the Lubmannian concept of a "person" is just specific to one of these visions, i.e. applicable only to a Western culture?

H-G M: I like Unger's classification, but never heard of it before. What he says about Confucianism strikes me as especially relevant. I think that religion in world society is not so much characterized by the global reach of religions (which, as you say, now often exists), but by the fact that religion is systemically integrated into functional differentiation, that it functions as one system within the environment of others and relates to them in this way. In a premodern context religion was not merely a function system, it sometimes claimed to be either the center of or a higher stratum in society. Radical Islam, for instance, might want to conquer the world and spread everywhere, but it is not content to merely being a function system within world society. It may want to become the global religion, but it does not seem to want to co-exist next to a "secular" law and "secular "politics". Modern globalization of a religion therefore 
does not simply mean geographical extension, but integration into a functionally differentiated modern world society. In general, I think Luhmann's theory of the "person" (as the social dimension of individuals) is not grounded in any religion, but his investigations into the semantics of individuality are sometimes quite "Eurocentric".

\section{Could you tell us a little bit about your current project on "identity profiling" and} second-order observation?

H-G M: I am currently working on a book, together with Paul D'Ambrosio, with the title You and your profile: Identity after authenticity (Moeller \& D'Ambrosio, 2021). It is supposed to show how profile-based identity - what we call "profilicity" - has widely replaced individuality-centered authenticity and an older rolebased "sincerity" as the most prominent mode or technology of selfhood. In short, sincerity demands commitment to roles, authenticity the pursuit of originality, and profilicity the curation and projection of (personal) profiles. Profilicty corresponds to a society that operates with "second-order observation", generating a need to present oneself with an appeal to "general peer" groups, which vary depending on the forum. We show ourselves in ways we like to be seen as being seen in public or by an audience. According to Luhmann (2012a, p. 100), second-order observation "has become the advanced mode of perceiving the world in modern society" (Luhmann, 2012a, p. 100) since "all functional systems were adapted operationally to secondorder observation" (Luhmann, 2012b, p. 87). It is a decisive feature of modernity and supplies the social framework within which profilicity functions. Profilicity not only shapes individual and collective identity ("national identity"), it also creates value in the economy ("from brand to profile") - or in any other system such as the academic system. Profile-building changes the focus from functional differentiation to second-order observation, which used to get not so much attention. However, the latter may be a concept much more powerful for understanding the world since Luhmann's death two decades ago. Do we really have functional differentiation in Brazil and China? It's problematic, but we definitely have second-order observation, and this is an equally crucial point of modern society. Of course, there is a connection: mechanisms of second-order observation have developed within functional systems, so it became important on the basis of functional differentiation. Profilicity has been preceded by authenticity and sincerity, as previous modes of identitybuilding. Prestige and reputation were built by performing roles in a community, on the basis of first-order observation. Now, personal identity and value are built through second-other observation, we have to convince the "general peer", sometimes in global, digitalized forums. For instance, during my lifetime the academic system 
has almost entirely switched to second-order observation: we don't need to read one another's texts, this is now often unnecessary! Instead, we look on these rating and raking mechanisms, we look at people's curricula, on where have they published, how much they have been cited, what do other people say about them. We don't look at someone's work directly, we observe some second-order mechanism, institution, or authority. This is very much the case for universities, with rankings. In order to understand and posit the place of some university in the academic system, we look to the rankings, and not directly to the university. The peer-review system is also a mechanism for second-order observation: a journal looks how a paper is observed by the peers. This is what counts. In the old days, the journal editor would personally evaluate an essay. This tends no longer to be the case. We have to see how this paper is being observed. Seeing something as it is being seen. Marxists need to learn that value and profit is no longer established through first-order observation (as in the $19^{\text {th }}$ century, when Marx wrote about "surplus value"). Elena Esposito (2011) uses Keynes to show how economic value is established by finance, by second-order observation within the economic system. Esposito points to Keynes example of the beauty contest, written in the 1930 's. Apparently, this worked not as a jury directly evaluating women, how do they look, and then voting. This would be first-order observation. Instead, people had to guess which woman other people would consider the commonly regarded most beautiful one She may not be the one that most voters consider the most beautiful, but the one that most voters consider as being generally considered by public opinion as the most beautiful one. This is how financial markets works. This erases first-order observation. It is not simply about my personal taste, nor a guess on each other's individual taste. This is how an investor would consider the value of a company from the viewpoint of the stock market, generally. Now this spread to other systems: in academia, we don't look to a paper and consider if we really liked it, we ask how it appeals and appears, if it could be published in a topranked journal or not. And we must write our papers considering the perspective of a high-profile journal. Politics also has not only been corrupted by other systems, but is being part of this dynamics of shifting towards second-order observation. This is how value is established in various systems.

\section{How do you relate this to the idea of a digital society?}

H-G M: The core idea is that digital society flourished because it provides a forum where second-order observation can be performed. We have this constant rating and ranking thing there, when we travel, when we go to a restaurant, when we take a cab by some app, and on the social media, the "likes" on YouTube. We orient ourselves towards second-order observation. The virtual world works on this basis. 
I think there is also a concept under-developed by Lubmann, which is the idea of "public spheres" as internal environments for each system. For instance, politics only answers to what comes to be a topic in its public sphere, which is the public opinion. And Lubmann didn't say what is the legal public sphere; I try to work with the idea of legal personality, how does law profile the legal subject, by courts and claims, butpresupposing a programming from politics or from economy, through legislation or contract.

H-G M: And the law firms are increasingly subjected to rankings, to second-order observation. The audience is institutionalized through the authoritative observer, which are the ranking agencies. Why are the rating agencies the most important thing in the economy? Is this a new form of capitalism? Your job depends on the rating of the rating agencies. The audience is not the people, it is a much more specialized network. Is there anything like that concerning courts?

For instance, the National Council of Justice in Brazil ranks and controls the judges and courts. In order to advance in your career as a judge you need to rank well in the criteria of the National Council of Justice. But we need to point out that the rankings not always correspond to our first-order observation. For instance, this week Brazil got the best grade in an economic evaluation in ten years, but in our immediate perception, this is the worst time in the decade. This shows how second-order observation may be decoupled from first-order observation. And, from a Marxistpoint of view, one could see the spreading of second-order observation as a kind of second-level colonization driven by the economy: economic second-order observation and procedures are spread throughout other systems, like in assessments of academic productivity, or prisons management efficiency. This limits second-order observations that are elaborated by each system in their own terms. The way to detect problems and prescribing solutions is always based on methods provided by economics and on the economic operations and organizations, all is seen through the lens of enterprises, production and service provision.

H-G M: Yes, I think so. And this is all new. Twenty years ago, there wasn't this presence of academic rating agencies, and also in the publication system. But I have the thought that the authoritative second-order institution is some powerful organization regarded as such, and then it comes to control the generation of value. It is not that the richest university gets the highest academic profile, but the highest profile university may then turn to become the richest university. After getting the certification you get the money. The target is internal to the scientific-educational system. If we publish on high-profile journals, then we are expected to get a higher salary or position. 
In the wake of the influential Foucauldian analysis of "biopolitics" many scholars tend to describe our predicament as a neoliberal one. Neoliberalism has been depicted as "the new reason of the world" (Dardot \& Laval, 2017) and this implies the extension of an economic grid of intelligibility throughout different social spheres and the domain of subjectivity. This implies also that public organizations chiefly operate with economic (external) criteria (to give just an example, there is a growing body of literature about "academic capitalism" and the economic corrosion of the university's autonomy, not only in relation to its funding mechanisms but also in relation to its day-to-day inner workings). Would it be possible to devise in this new "primacy of the economic" as a challenge to the primacy of functional differentiation? Does this trend jeopardize that which the concept of "structural coupling" attempts to describe, i.e. a pattern of relationship between different social systems in which the operational autonomy of the system is preserved?

H-G M: I think claims of "academic capitalism" (or "surveillance capitalism") are slightly misleading. It is without question correct, though, that the economic system is extremely powerful in its couplings with other systems, such as academics, education, politics, mass (social) media, etc. We should not only look at "functional differentiation", however, to understand how the economy and society (or "the world") has changed. I suggest to look instead at second-order observation first. Once we understand how the construction of value has changed in the economy, we can understand how "value" has changed throughout society. Today value is not simply monetary value, or capital. In the economy, financial value is "profile" value - how something is seen as being seen - for example how something is rated by rating agencies or on the markets. This kind of profile value is not only reshaping the economy, but also, since you bring it up, the university. A university is not primarily concerned with how much money it makes, but with its rating and rankings, with its profile. And this is the same for academics; You, too, must first and foremost take care of your academic profile as it manifests itself, for instance, in your $\mathrm{H}$-index, in the number of your citations, in the reputation of the journals where you publish. Your salary will follow suit. "Democratic" politics, too, are no longer primarily about e.g. changing or maintaining the mode of production. They are profile contests and consist in constant polling - in "social validation feedback loops". As Luhmann says: "One can only become the leader if he is capable of manipulating how he is observed" (Luhmann, 2012a, p. 119). Of course, money still helps with such manipulations. We should therefore speak of "profile capitalism", "profile academics", "profile politics" etc. The "primacy of the economic' of which you speak is itself subject to a "primacy of the profile" - or of second-order obser- 
vation. This does not impede functional differentiation. To the contrary, profiles, and profile value, emerge through the operational modes of the different function systems (economy, politics, social media, academics etc.).

There is increasingly a tendency to erode of the meaning of democracy today. Ideas like "they don't represent us", the demise of traditional political parties (in Brazil we could identify the cases regarding Workers Party and the Social Democratic Party results in the last election) and the election of political outsiders in some manner represent a crisis in the political representative system. For Luhmann democracy is not actually a pure ideal; he addresses this issue by highlighting its operational features inside the political system, like the relation between government and opposition and the idea of decomposition of decisions on other decisions, through representation or participation that may overburden the system. But, still, could we observe a rupture of the democratic process today? Specially observing the rise of the extreme right and the nationalist groups in politics? In your book The Radical Lubmann (Moeller, 2011) you mention that political variety can increase so much that it eliminates political redundancy. Could this be an important approach to understand the problem of stabilization of the political system today?

H-G M: Democratic political contests today are profile or identity contests under conditions of second-order observation, and the religious or civil religious discourse that is increasingly utilized by it has the function of supporting or shaping political profiles (of political organizations, parties, and voters). To explain the "meaning of democracy today", Luhmann presents a short and almost poetic description of the democratic political process as a profilicity competition - without using this concept, though:

Children, simply out of fear, always needed to observe if they are observed or not. [...] The same is true in politics. Politics must dance on the screen in front of public opinion. In spite of all the polls, no politician knows for sure what people really think. At best, one knows, statistically calculated, what some people say they think. It is unimaginable that politics or a politician could know, or merely take into consideration, what is going on in the heads of individuals. Public opinion [...] is a replacement for this. Politics thus essentially consists in arranging how one is seen by public opinion - so that one is more favorably observed than the competition. [...] The truly political [das eigentlich Politische] is the reflection of second-order observation (Luhmann, 2012a, p. 115).

The radicalism of this statement needs to be highlighted. That politics - left and 
right, blue and red, and of course equally so green and pink - can be understood in terms of a populist "dance on the screen" is nothing new. And even if the concept "populism" was not used in Luhmann's days in the way it is now, it was already obvious then that democratic elections were typically decided by the popular appeal of the profiles of politicians or political parties as manifested in their looks, their "charisma", their campaign strategies, their capacity to instill hope or fear in the electorate, rather than by the electorate's rational consideration of its best interest or its political will. All this has been surely the case in politics then and now, but Luhmann goes a step further in his analysis when he points out that modern politics consists "essentially" in this - that the "reflection of second-order observation" has now become das eigentlich Politische ("the truly political", or "politics proper", or "politics as such"). Not only are elections run as profilicity contests, but politics generally function in this way. When decisions are made and power is executed, the prime concern is "arranging how one is seen by public opinion". The election is not an exceptional case of periodically consulting the "will of the people". Like the anxious children of "helicopter parents", politicians never get a break from observing if and how they are observed. Their "dance marathon" never ends. As for the contestants in Sydney Pollacks' They Shoot Horses, Don't They?, everything a politician does - marrying, for instance - becomes part of a competitive performance to the general peer. Thus, the political is in essence "depoliticized": in contemporary liberal democracies (arguably unlike in authoritarian states) there is no first-order observation politics left where politicians make decisions merely for the sake of governing the state without considering how this is being observed. Political identity, and the identity of politicians, has become totally profilic. Political profilicity is, in this sense, "totalitarian".

What we have been discussing on second-order observation seems close to the concept of reflexivity in Luhmann. Direct democracy is no longer possible, so we don't decide directly on the polity politics, we decide who will define the policies for us. Representation came as a second-order observation, reinforcing politics as a specialized system, as a subsystem of society, and not as coextensive to it. The same for financial markets in economy, there is the definition of value. And the homologous instance for law is the constitution: every interpretation or norm is valued according to the constitution, which is an instance internal to the legal system, validity not depending on a dense moral or political consensus.

H-G M: I can think of a future legal system where the courts would not be anymore the core organization, but there may be a core rating institution that will rank and supervise courts: is this a three-star court or a five-star court or judge? 
And maybe the State would not control anymore the courts and judges, but only this rating authority. Courts and judges may be private. Transnational and international organizations compare legal orders, rating for instance each national antitrust law. This already exists. For some sociologists the digital "reality" represents an extensive capability for monitoring, analyzing and informing social systems. It is possible to discuss if the digitization of society makes possible a new way of knowing and operating in society, hence the "digital" could refer to a topic of social enquiry, but also as an instrument/method of research, or even a form of communication. Do you think that the digital technology has changed the possibility of observing society? Is there a space for a digital sociology in Lubmann's theory? How could this issue be properly addressed?

H-G M: Thanks for the term "digital sociology". While you seem to think of this term in analogy to "digital humanities" in a methodological and empirical, way, I would take it up in a different, theoretical way as describing the project of a theory of "profilicity", or of identity in a society that has almost entirely switched to second-order observation. Although digital society (social media, surveillance, rating and ranking systems. algorithms, etc.) did not create profilicity, it facilitates profilicity greatly. Digital society thrives because it can enable profilicity, which is second-order observation identity, to operate, function, and proliferate. In order to understand how contemporary society has evolved after Luhmann's death, we need a "digital sociology" both in the empirical way you seem to think of and in the theoretical way I have in mind.

There is no consensus on the concept offake news today. Numerouspossibilities to define its meaning are offered by the literature: post-truth; misleading information; mal-information; disinformation; biased news amongothers. Moreover, for some sociologists, fake news is not a new phenomenon - perhaps it just got more "present" due to the social media -, yet we can notice the increase of medical fake news, political fake news and so on. What would be a Lubmannian approach towards fake news? How we can observe the fake news operation in social systems? Does fake news impose any kind of danger for the functional differentiation of the systems?

H-G M: "Truth" has never been the medium of the mass media. They deal in information which is very different from truth. Luhmann (2000, p. 36) says: "Although truth, or rather the assumption of truth, is indispensable for news [...], the mass media do not follow the code true/untrue but rather the code information/non- 
-information". The mass media do not communicate simply "truth", although, they pretend to - just like the legal system does not simply deliver "justice", although it uses it as its contingency formula. "Pure" facts do not exist - "factuality" may be regarded as the "contingency formula" of the mass and social media. All news consists of information which becomes old information as soon as it is communicated and has to be replaced by new information - just as spent money needs to be speedily replaced by earned money in the capitalist economy. News are highly selected pieces of information that create narratives that can be continued. In this respect, news function very similar to the popular episodic TV series or soap operas. They operate by communicating narrative information that promise a sequel. Unlike in the TV dramas, however, the information we hear in the news is presented as "factual". We should not forget, however, as Luhmann points out, that these facts, as soon as they are selected as information, appear as incomplete because a) they create the need for further, supplementing and complementing facts/information, b) they become dubious because we can ask who presented them as information and for which reasons, and c) "selection always also generates that other side of the products presented, that is the non-selection or the 'unmarked space' of the rest of the world". (Luhmann, 2000, p. 37). To quote Luhmann:

\footnotetext{
The mass media are only interested in things that are true under severely limiting conditions that clearly differ from those of academic research. It is not the truth that is the problem, therefore, but rather the unavoidable yet intended and regulated selectivity. Just as maps cannot correspond exactly to the territory they depict in terms of size and details, and just as Tristram Shandy was not in a position to tell the life he lived, so also it is not possible to have a point-for-point correspondence between information and facts, between operational and represented reality (Luhmann, 2000, pp. 26-27).
}

The traditional mass media have invented the term "fake news" to present themselves as the "real news" producers rather than the social media at a time when their power has been severely undermined by social media. They thereby falsely imply that they are capable of telling "the truth" rather than communicating information - that is: highly selective data shaping narratives addressed to an audience to produce an effect. Among other things, news narratives shape identity profiles through establishing "social validation feedback loops". The profiles of The New York Times or Fox News and those of their readers/viewers are shaped through the communication of news/information. The New York Times shapes the profiles of its readers while these readers shape the profile of The New York Times in turn. The very fact that the term "fake news" is now so popular as a sort of rhetorical weapon (Trump, too, uses it all 
the time) - shows that news is not so much about communicating truth but about developing story lines or narratives which, through structural coupling, can produce benefits in democratic political contests or in a capitalist economic competition.

Thanks for this conversation.

São Paulo, 2019.

\section{References}

Dardot, Pierre \& Laval, Christian. (2017), The new way of the world: On neoliberal society. Translated by Gregory Elliott. London, Verso.

Esposito, Elena. (2011), The future of futures: The time of money in financing and society. Cheltenham, Edward Elgar.

Habermas, Jürgen. (1987), The philosophical discourse of modernity: Twelve lectures. Translated by Frederick Lawrence. Cambridge, MA, MIT Press.

Luhmann, Niklas. (1990), Political theory in the Welfare State. Translated by John Bednarz Jr. Berlin, De Gruyter.

LuHmann, Niklas. (1997), "Globalization or world society? How to conceive of modern society". International Review of Sociology. London, 7 (1): 67-79.

Luhmann, Niklas. (2000), The reality of the mass media. Translated by Kathleen Cross. Stanford, Stanford University Press.

Luhmann, Niklas. (2012a), Introduction to systems theory. Translated by Peter Gilgen. Cambridge, Polity.

Luhmann, Niklas. (2012b), Theory of society I. Translated by Rhodes Barrett. Stanford, Stanford University Press.

Moeller, Hans-Georg. (2006), Luhmann explained: From souls to systems. Chicago, Open Court.

Moeller, Hans-Georg. (2011), The radical Luhmann. New York, Columbia University Press.

Moeller, Hans-Georg \& D’Ambrosio, Paul J. (2021), You and your profile: Identity after authenticity. New York, Columbia University Press.

Unger, Roberto Mangabeira. (2014), The religion of the future. Cambridge, MA, Harvard University Press. 
Texto recebido em 17/02/2021 e aprovado em 15/06/2021.

DOI: $10.11606 / 0103-2070 . t s .2021 .182052$

Laurindo Dias Minhoto is Associate Professor at the Department of Sociology of the University of São Paulo. E-mail: lminhoto@gmail.com.

Lucas Fucci Amato is Assistant Professor at the Law School of the University of São Paulo. E-mail: lucas.amato@usp.br.

Marco Antonio Loschiavo Leme de Barros is Assistant Professor at the Law School of the Mackenzie Presbyterian University. E-mail: marcoloschiavo@gmail.com. 